\title{
Analysis of Soil Nutrients based on Potential Productivity Tests with Balanced Minerals for Maize-Chickpea Crop
}

\author{
Mr. H. James Deva Koresh, \\ Research Scholar, \\ Karunya University, \\ Coimbatore, India. \\ Email id: jamesdeva@karunya.edu.in
}

\begin{abstract}
Generally, a soil nutrients test has been performed for determining the productivity measures of any plant. It includes many challenges of environmental impacts and climate adaptation. To maintain the crop nutrients quality without affecting previous performance from the soil, it is required to minimize the challenges in the soil health sector can be increased economic returns from crop productivity. This article represents the review on improving productivity for soil nutrition. Soil nutrition was tested and assessed using the existing method, and deficiencies in the soil were identified that could be improved using some standardized methods. This productivity function of soil supply is measured by a various spatial scale which is a part of this research. The objective aims to achieve high productivity in the context of soil and also to realize environmental impact for soil functionality, productivity function, and resources information. The classification of soils corresponding multitude of approaches developed globally for potential soil productivity. The main focus is to determine strategies for the effects of a balanced nutrition system of maize-chickpea. The treatment and control can be developed and tested every year on crop yield. Besides, this research presents a future enhancement of improved productivity tests for a balanced soil nutrition system for better crop yield. The soil classification will be categorized with a knowledge base algorithm for further accuracy for the system.
\end{abstract}

Keywords: Soil nutrition, Crop productivity

ISSN: 2582-3825 (online) 
Journal of Electronics and Informatics (2021)

Vol.03/ No.01

Pages: 23-35

https://www.irojournals.com/iroei/

DOI: https://doi.org/10.36548/jei.2021.1.003

\section{INTRODUCTION}

The word "Agricultural Sustainability" comprises a crop yield system, unstoppable food production, maximum crop yield, and without affecting the environmental impact. Increased population and decreased food production due to soil nutrition reduction provide less in many essential basic things goods for human. Healthy soil provides a vibrant living system that contains many green ecosystems, water excellence, harvest efficiency, soil recycling, nutrient decomposition, and extracting many minerals from the ground [1]. This micro-organism range can be a component of soil health. Generally, soil health and crop quality are directly proportional to each other. It includes soil health metrics that can be evaluated the quality of soil nutrition. The yielded result in soil health management increases food insufficiency to meet demands currently. Therefore, this soil health is a vibrant research area in the agriculture sector to examine many parameters for climate adaptation and environmental impact [2].

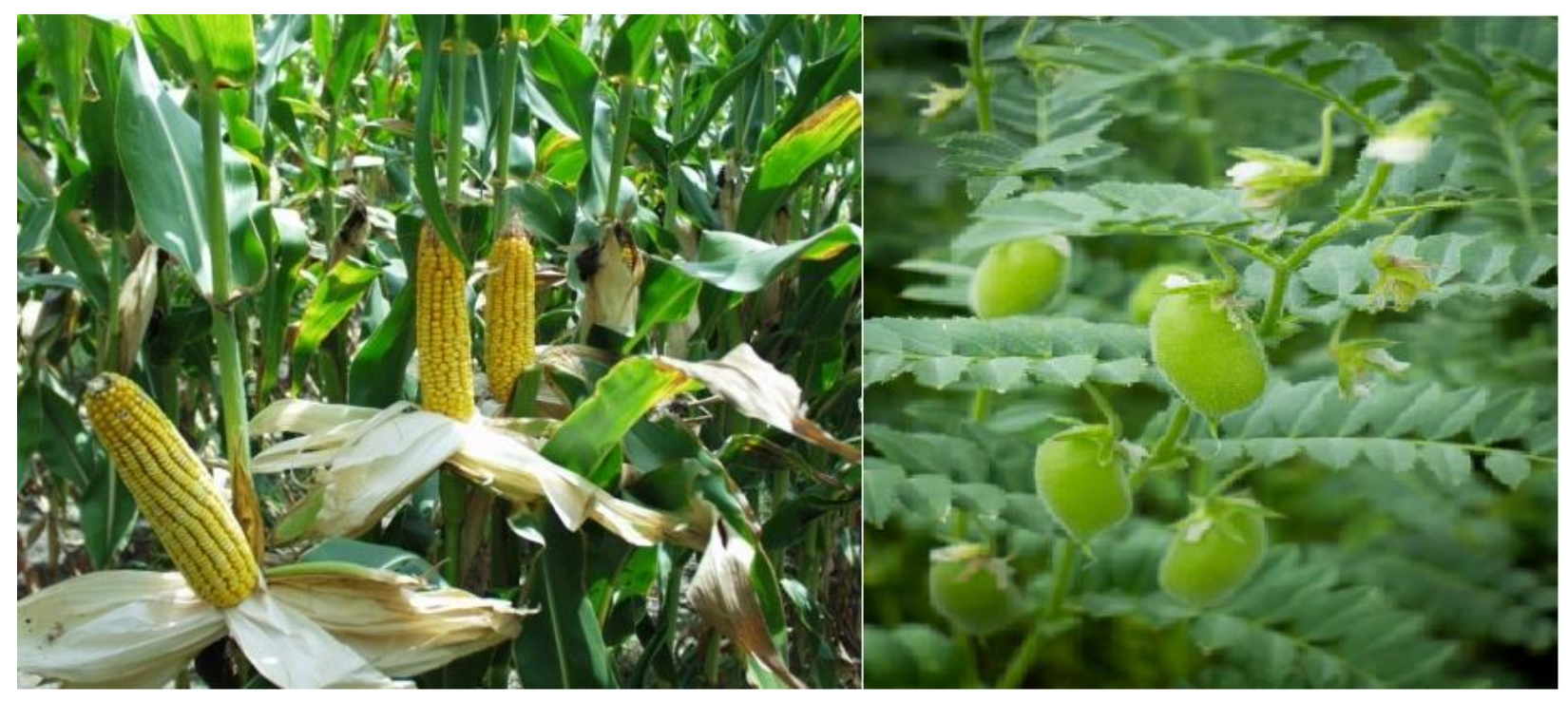

Figure 1 Images of Maize - Chickpea Crop

The soil health methods provide increased crop yield and continuous harvesting impact, as well as a better understanding of the area of interest improvements. Besides, this measurement of the potential of Hydrogen $(\mathrm{pH})$ in the soil provides successful cultivation and improved productivity of the crop. Healthy growth can be adjusted to the environmental impact. This routine 
Journal of Electronics and Informatics (2021)

Vol.03/ No.01

Pages: 23-35

https://www.irojournals.com/iroei/

DOI: https://doi.org/10.36548/jei.2021.1.003

and balancing the checking of $\mathrm{pH}$ of soil provides development of crop production [3]. The less $\mathrm{pH}$ levels will take to many diseases or the death of the plant. Generally, this measurement is a quantitative calculation between $\mathrm{H}+$ and $\mathrm{OH}$ - ions in the water. This scale range must be 0 to 14 for all conditions. Above 7.0 is indicating the neutral point of the measurement mid-value. Also, more alkaline content can be found in soil when it is green, yellow, or orange, indicating that the soil is more acidic. Usually, this identification can be defined and identified by its color. For the more accurate soil $\mathrm{pH}$ measurement can be done by the measuring meter for designing the soil [4]. The soil sample can be collected for analysis at any time of year and will yield good results and it also aids to improve productivity and maintain nutrition in the soil for a long time with greater efficiency. When it comes to soil tests, there are numerous procedures that must be followed both after and before fertilizer application in order to achieve higher yields. Generally, immediate soil tests will not provide good results for productivity due to the viewing of many chemicals [5]. After two months of fertilizer application, a soil test should be performed. This procedure method is selected in this research to be the take-up of our productivity improvement.

\section{ORGANIZATION OF THE RESEARCH}

The structure of this article is organized as follows; Section 3 provides related works of productivity tests for soil nutrition. Section 4 discusses the methods to analyze the productivity tests for future modernizing trends. Section 5 comprises of obtained results and discussion. Finally, Section 6 concludes the research work.

\section{RELATED WORKS}

Petropoulos et al expressed the soil moisture content that consists of dimensionless ration expression as numerical value [6]. Dobriya et al., present soil moisture estimation will be classified in direct and indirect methods. The direct method is that finding the numerical value from the soil between wet and dry state. The indirect method is used to determine the calibration measurable method. Besides, the presence of radiation and dielectric methods determines the measurement for the productivity of the soil. This observation of soil moisture provides volumetric moisture content and the merits and demerits were discussed [7]. Dorigo et al., the authors have considered the basic technique to measure the soil moisture content by a gravimetric method which is used to measure 
Journal of Electronics and Informatics (2021)

Vol.03/ No.01

Pages: 23-35

https://www.irojournals.com/iroei/

DOI: https://doi.org/10.36548/jei.2021.1.003

directly. The samples are taking directly from the field and weighing after and before dry of soil [8]. Seneviratne et al., discusses the direct method to determine soil moisture content through the derivation of absolute and relative properties of the soil [9]. The dryness of soil is time-consuming for processing which is the limitation of this method. Additionally, conversion error occurs due to volumetric soil bulk density [10].

Bunemann et al., proposes the framework for healthy soil based on productivity measurement and discussed consensus for healthy soil. Soil health links can be developed for assessment tools for agronomic inference. The soil healthy baffled with many modern yield data for rarely evaluation framework. These studies are reporting for soil health and crop production management system with the normal condition [11]. Oldfield et al., discusses soil health (SH) indicator for many parameters such as biological, chemical organic inputs are limited to work naturally [12]. Lal et al., the authors works in improving SH management interaction with specific controls relationship. This relationship has been explained with merits and demerits [13]. Lucas et al., the authors have mentioned the relationship in improving SH management system for stability and soil system along with dataset comparison. Many research articles depict the composite material for SH to crop yield. The practice for developing crop yields in the healthier soil the productivity influence is healthy. SH data can be used to alert soil nutrition for productivity, based on crop yields that can be induced and promoted to maximize soil health [14]. Many research papers have identified four common principles for improving soil health and enlightening productivity. The first is that soil perturbation should be kept to a minimum. The second is that crop plant variety should be increased as much as possible. The third is to mention that the crop's living roots should be carefully monitored throughout the year. Finally, the soil coverage should be maximized for many crop yields. This procedure should be circulated for conservative agriculture. Gupta et al., proposed this procedure for the implementation of soil health [15]. 
Journal of Electronics and Informatics (2021)

Vol.03/ No.01

Pages: 23-35

https://www.irojournals.com/iroei/

DOI: https://doi.org/10.36548/jei.2021.1.003

\section{METHODOLOGIES}

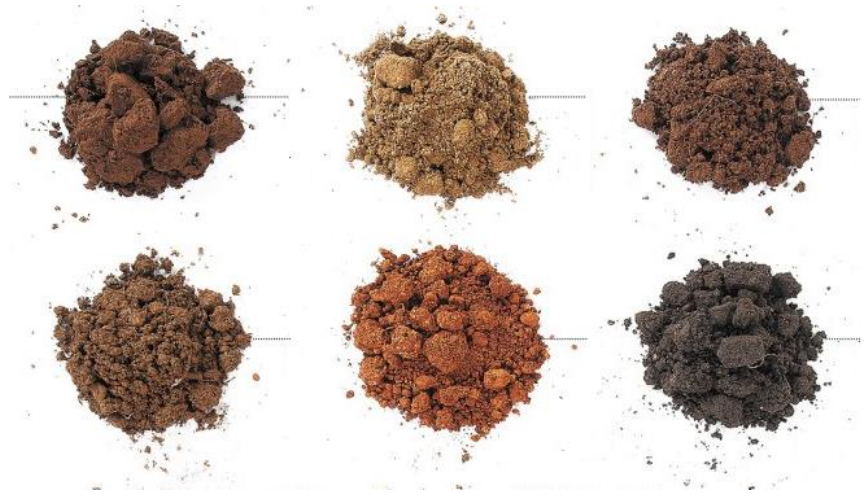

Figure 2 Mineral measurement for different soil

\subsection{Soil and land rating}

There are numerous methods for rating soil or land, each with a set of evaluations and classifications. In the last decade, the productivity potential has been developed accordingly. The soil and land survey was carried out using a high coverage mapping area [16].

\subsection{Soil Evaluation}

Based on soil rating, the evaluation will be taking place for productivity tests in the soil. In general, the agriculture productivity function necessitates a number of several other parameters such as environmental impact, climatic condition, human activity, and so on.

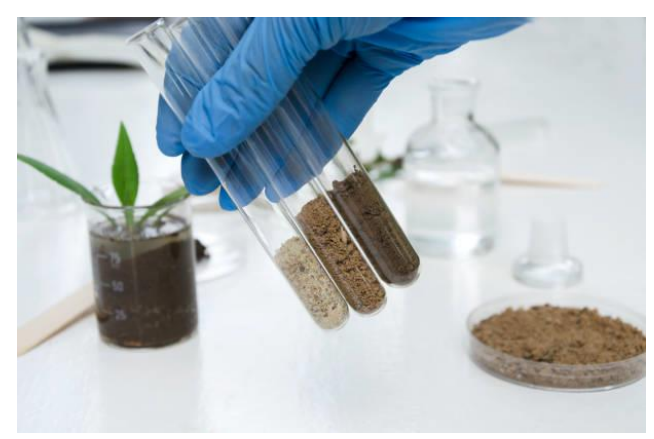

Figure 3 Soil test for productivity

ISSN: 2582-3825 (online) 
Journal of Electronics and Informatics (2021)

Vol.03/ No.01

Pages: 23-35

https://www.irojournals.com/iroei/

DOI: https://doi.org/10.36548/jei.2021.1.003

The land evaluation method is used to check the productivity capacity of soil in the land. Also, it measures the land performance for specific crop yields. Our proposed method consists of this method to evaluate maize-chickpea crop cultivation [17]. This method was initiated and developed by applied system analysis in an international institute of agroecological organization. Besides, our proposed method provides a framework with many parameters such as soil property, soil and land historical context with climatic property for our relevant agriculture maize-chickpea crop cultivation. The estimation of specific maize-chickpea cultivation over the land area with mapped and calculated by suitable class-based productivity test [18]. Recently, a digital soil map of the world was obtained and the region of interest with climatic conditions for system processes of soil detailed information was discussed. In this method, a significant characterization with climatic impact and its important role were covered.

\subsection{Methods of soil testing}

This soil evaluation will be continued with soil testing based on the historical context of the soil. There are many methods to analyze soil testing is given here as follows;

1. Machine driven analysis

2. Compound analysis

3. Agrochemical analysis

4. Mineralogical testing

5. Toxicological testing

6. Microbiological testing

Before the soil testing, some basic parameters should be characterized, for example, fertility, contamination with pathogens studies. Generally, the fertility test is consisting of physical and biological, chemical parameters. Then the contamination test method consists of fungi and virus and bacteria, radionuclides parameters. Sometimes this parameter is analyzed due to the immediate effect of plant growth [19].

ISSN: 2582-3825 (online) 
Journal of Electronics and Informatics (2021)

Vol.03/ No.01

Pages: 23-35

https://www.irojournals.com/iroei/

DOI: https://doi.org/10.36548/jei.2021.1.003

This type of analysis is used to measure particle size for crop yield which is related to granules for soil analysis. This distribution can be measured section-wise based on diameter and weight. Also, the type of soil can be measured to estimate how much clay and sand part present in the soil. A compound analysis test can determine the various nutrition content of the soil. This test can reveal the soil absorption capacity of any type of land. Furthermore, the acidity level and the importance of fertiliser for specific crop yield. Many compounds, including copper, zinc, nickel, and arsenic, can be measured using this test. It finds the $\mathrm{pH}$ and pollution level of the soil. The soil can be categorized dangerous level for plant cultivation method. With the help of an agrochemical test, there is the determination of the various chemical concentration and effects of crops and plants. Mineralogical analysis can be used to determine the mineral content of soil as well as its quality [20]. The toxicological test is used in many soil laboratories to detect the presence of toxic levels in the soil. Finally, the soil microbiological test can determine and classify the bacterial, virus-affected, and fungi region. Besides, biological activity and micro-organism can be determining the causes of the crop yields sector.

\subsection{Caring of soil nutrition and crop yields}

Soil disturbance is one of the challenging tasks in the crop field. Based on a machine-driven test the soil disturbance can be calculated and minimized with absolute function. It is very important economic and environmental terms. A simple solution is rich nutrition is maintaining by minimizing the soil disturbance [21]. The agricultural land should be benefited through the multidimension ecosystem and preventing nutrients losses, and the cultivation through the cycling process is called covering crops.

\subsection{Test for stability and resilience reaction}

The measure of reliability and stability of the production from the crop based on soil health occupies many forms with environmental impact. The wet and dry climatic changes can stabilize and provide a resilient reaction to the climatic impact. 
Journal of Electronics and Informatics (2021)

Vol.03/ No.01

Pages: 23-35

https://www.irojournals.com/iroei/

DOI: https://doi.org/10.36548/jei.2021.1.003

\subsection{Soil classification based on its capability}

The productivity-based classification of soil has been mapped many agricultural land limitations, for example, steep, wet, dry, and stony land types [22]. In general, capability is classified based on historical land context data, climatic impact, and environmental pollution. The medium-scale capability classification is based on land information. The soil suitability includes the productivity potentials for growing maize-chickpea cultivation specific [23]. Maize production increases the certain stratification on the crop orientation fields and agricultural soil quality can be refereed with many cycling processes of soil health. This soil suitability is developing here with soil structure phenomena and capability is increasing based on climatic data within the region of the land. As a consequence, the climatic change parameter can also be used to identify land capability in future developments [24]. The proposed method approaches climatic conditions in primary to predict the improvement of maize-chickpea productivity.

\section{RESULTS AND DISCUSSION}

The minerals will not be distributed evenly throughout the soil. As a result, proper alignment and procedures should be followed when collecting soil samples from the land. A soil shovel is used to dig 6 inch depths in the land for maize-chickpea crop yield in our proposed methodology. For example, the Sulphur test requires a 20-inch dig in the ground. The different crops have been planted in various parts of the region of the land. The productivity of the plant depends on the minerals or nutritional content of the soil. The intelligent selection of mineral details in the soil is essential and very important for high yields. Farmers frequently overestimate the need for fertilizers. However, this is not recommended due to unreliability in sometimes particularly rainy climatic conditions. 
Journal of Electronics and Informatics (2021)

Vol.03/ No.01

Pages: 23-35

https://www.irojournals.com/iroei/

DOI: https://doi.org/10.36548/jei.2021.1.003

\section{Minerals Range during Soil Test}

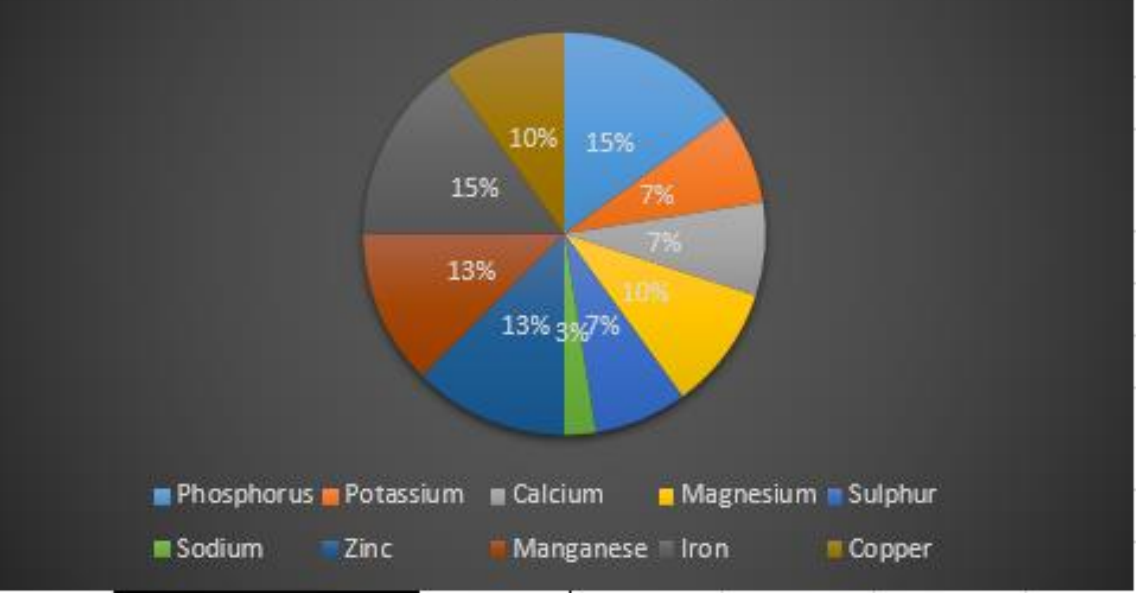

Figure 4 Minerals ranges during soil test

Proper soil collection is required to improve the accuracy and analysis of the test results. Figure 4 shows the various minerals ranges during soil tests. For soil health, all should be in the optimum range is very ideal. The approximate results can be set to obtain the optimum values. Table 1 shows the obtained values from various minerals tests for the sample soil.

Table 1 Minerals Ranges / level indication during soil test rating

\begin{tabular}{|c|l|c|c|}
\hline S.NO & \multicolumn{1}{|c|}{ TESTS } & RESULTS & $\begin{array}{c}\text { RANGES / LEVELS } \\
\text { CONSIDERATION }\end{array}$ \\
\hline 1 & Soil $\mathrm{pH}$ & 6.4 & \\
\hline 2 & Phosphorus & $109 \mathrm{PPM}$ & NEARLY VERY HIGH \\
\hline 3 & Potassium & $102 \mathrm{PPM}$ & MODERATE \\
\hline 4 & Calcium & $1300 \mathrm{PPM}$ & MODERATE \\
\hline 5 & Magnesium & $175 \mathrm{PPM}$ & REQUIRED AMOUNT \\
\hline 6 & Sulphur & $18 \mathrm{PPM}$ & MODERATE \\
\hline 7 & Sodium & $22 \mathrm{PPM}$ & VERY LOW \\
\hline 8 & Zinc & $7.9 \mathrm{PPM}$ & OPTIMUM \\
\hline 9 & Manganese & $49 \mathrm{PPM}$ & OPTIMUM \\
\hline 10 & Iron & $200 \mathrm{PPM}$ & VERY HIGH \\
\hline 11 & Copper & $0.6 \mathrm{PPM}$ & REQUIRED AMOUNT \\
\hline
\end{tabular}


Journal of Electronics and Informatics (2021)

Vol.03/ No.01

Pages: 23-35

https://www.irojournals.com/iroei/

DOI: https://doi.org/10.36548/jei.2021.1.003

Figure 5 depicts the process of obtaining value by categorizing ranges for good soil health. These methods are very transparent and perfectly calculated, and the experienced specialist decision appears. This due to the cost of production is inversely proportional to the presence of minerals and nutrients in the soil. Many plants that are sensitive to harsh weather conditions will be harmed by the conditions.

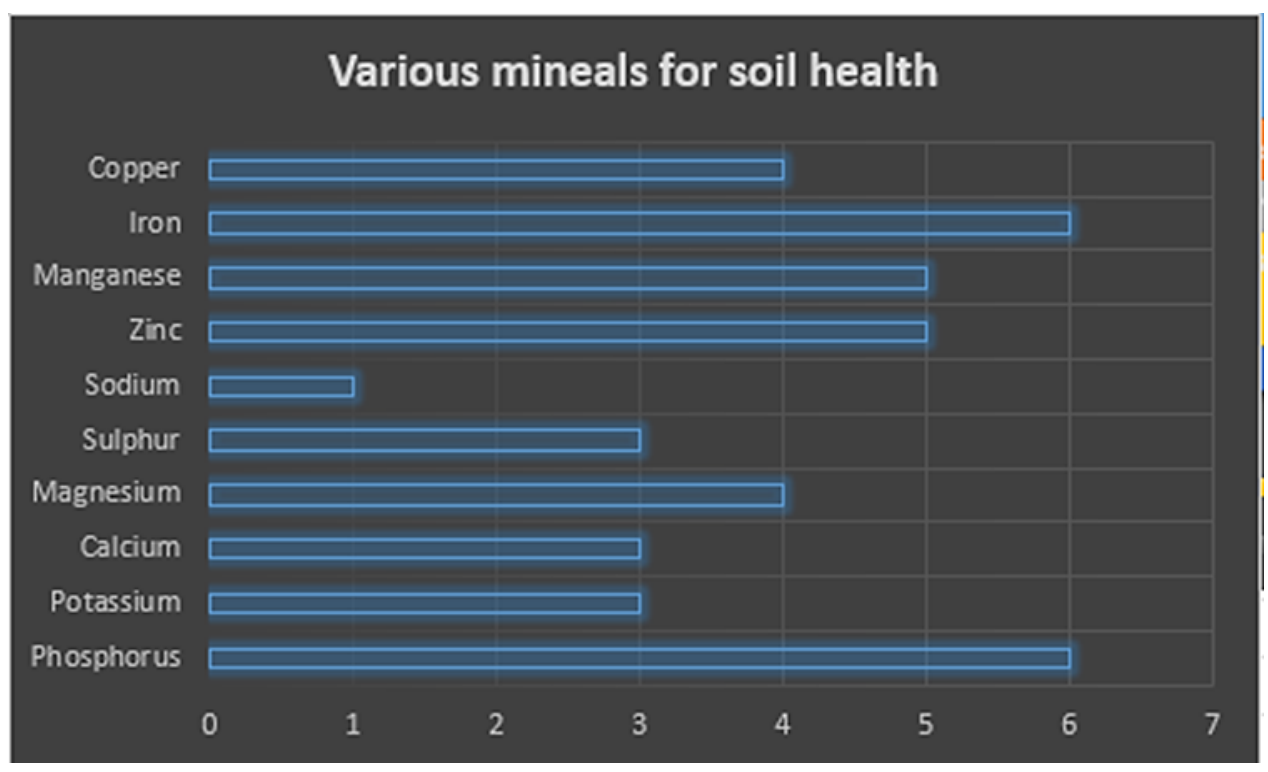

Figure 5 Calculation of Soil Health requires minerals

Our proposed test was mostly low fertility and it distributed to crop yields. Because of its low $\mathrm{pH}$ level, the maize-chickpea crop will be exposed to compound and fertilizer, causing it to degrade the soils. Then acidity is the big challenge of soil fertility that leads to unproductive and unavailability of minerals soon. It can be damaged the crop soon.

\section{CONCLUSION}

This soil health management method is very essential in any land to protect from the unproductive or impotent stage of crop yields. Thus, the proposed method was tested and various mineral levels in soil with the classification were calculated. Here, various tests is used to assess yield stability and resilience. This soil health management increases the productivity range and stability. The experiment results show the maximum of minerals must be in an optimum range 
Journal of Electronics and Informatics (2021)

Vol.03/ No.01

Pages: 23-35

https://www.irojournals.com/iroei/

DOI: https://doi.org/10.36548/jei.2021.1.003

with the proper sample collection from the land. To achieve high productivity from the soil for the same chickpea crop maybe of 2 times. Furthermore, for this agro prediction process, the environmental impact and climatic conditions were handled by a well-experienced qualified individual. Therefore, maintaining balanced nutrition provides increased productivity due to variation in water, dynamic nutrients, and low disease frequency. This is the strategy for maintaining the balance nutrition system for maize-chickpea crop. Furthermore, soil health increased metrics and practices can influence the nutritional quality of the plant. Crop quality and yield stability are measured using indexed soil health parameters. As a result, our test requires data for long-term experiments in soil with random climatic conditions in future development. The author strongly suggests that predicting the systematic procedure with a more in-depth knowledgebased learning algorithm can provide good impact and results for future achievement. The implementation of engineering technology in agriculture that manages plant nutrition with optimum water usage in an efficient manner will be the future work of this research.

\section{REFERENCES}

[1] Hunter, M. C., Schipanski, M. E., Burgess, M. H., LaChance, J. C., Bradley, B. A., Barbercheck, M. E., ... Mortensen, D. A. (2019). Cover crop mixture effects on maize, soybean, and wheat yield in rotation. Agricultural \& Environmental Letters, 4, 180051. https:// doi.org/10.2134/ael2018.10.0051

[2] IPCC. (2019). Summary for policymakers. In: P.R. Shukla et al. (Eds.), Climate change and land: An IPCC special report on climate change, desertification, land degradation, sustainable land management, food security, and greenhouse gas fluxes in terrestrial ecosystems. IPCC.

[3] Knapp, S., \& van der Heijden, M. G. (2018). A global meta-analysis of yield stability in organic and conservation agriculture. Nature Communications, 9, 1-9. http://doi.org/10.1038/s41467-018$\underline{05956-1}$

[4] Lal, R. (2020). Soil organic matter content and crop yield. Journal of Soil and Water Conservation, 75, 27A-32A. http://doi.org/10.2489/ jswc.75.2.27A

[5] Beal Cohen, A. A., Seifert, C. A., Azzari, G., \& Lobell, D. B. (2019). Rotation effects on corn and soybean yield inferred from satellite and field-level data. Agronomy Journal, 111, 2940-2948. http://doi. org/10.2134/agronj2019.03.0157

[6] Petropoulos, G. Griffiths, H. M., Dorigo, W., Xaver, A. and Gruber, A. (2013). "Surface Soil Moisture Estimation: Significance, Controls, and Conventional Measurement Techniques." In G. 
Journal of Electronics and Informatics (2021)

Vol.03/ No.01

Pages: 23-35

https://www.irojournals.com/iroei/

DOI: https://doi.org/10.36548/jei.2021.1.003

Petropoulos (Ed), Remote Sensing of Land Surface Turbulent Fluxes and Soil Moisture. Chapter2nd, Taylor \& Francis, pp. 29-48.

[7] Dobriyal, P., Qureshi, A., Badola, R. and Hussain, S.A. (2012). "A review of the methods available for estimating soil moisture and its implications for water resource management." Journal of Hydrology, 458-459: 110-117.

[8] Dorigo, W. A., Wagner, W., Hohensinn, R., Hahn, S., Paulik, C. et al., (2011). "The International Soil Moisture Network: a data hosting facility for global in situ soil moisture measurements." Hydrol. Earth Syst. Sci. Discuss., 8 (1609-1663).

[9] Seneviratne, S. I., Corti, T., Davin, E. L. et al., (2010). "Investigating soil moisture-climate interactions in a changing climate: A review." Earth-Science Reviews, 99: 125-161.

[10] Medhat, M.E. (2012). "Application of gamma-ray transmission method for study the properties of cultivated soil." Annals of Nuclear Energy 40: (53-59).

[11] Bünemann, E. K., Bongiorno, G., Bai, Z., Creamer, R. E., De Deyn, G., de Goede, R., ... Mäder, P. (2018). Soil quality: A critical review. Soil Biology and Biochemistry, 120, 105-125. http://doi.org/10.1016/ j.soilbio.2018.01.030

[12] Oldfield, E. E., Bradford, M. A., \& Wood, S. A. (2019). Global metaanalysis of the relationship between soil organic matter and crop yields. Soil, 5, 15-32. http://doi.org/10.5194/soil-5-15-2019.

[13] Lal, R. (2020). Soil organic matter content and crop yield. Journal of Soil and Water Conservation, 75, 27A-32A. http://doi.org/10.2489/ jswc.75.2.27A.

[14] Lucas, S., \& Weil, R. (2012). Can a labile carbon test be used to predict crop responses to improve soil organic matter management? Agronomy Journal, 104, 1160-1170. http://doi.org/10.2134/ agronj2011.0415

[15] Hobbs, P. R., Sayre, K., \& Gupta, R. (2007). The role of conservation agriculture in sustainable agriculture. Philosophical Transactions of the Royal Society B: Biological Sciences, 363, 543-555. http://doi. org/10.1098/rstb.2007.2169.

[16] Behnke, G. D., Zuber, S. M., Pittelkow, C. M., Nafziger, E. D., \& Villamil, M. B. (2018). Long-term crop rotation and tillage effects on soil greenhouse gas emissions and crop production in Illinois, USA. Agriculture, Ecosystems \& Environment, 261, 62-70.

[17] Blanco-Canqui, H., Shaver, T. M., Lindquist, J. L., Shapiro, C. A., Elmore, R. W., Francis, C. A., \& Hergert, G. W. (2015). Cover crops and ecosystem services: Insights from studies in temperate soils. Agronomy Journal, 107, 2449-2474. http://doi.org/10.2134/ agronj15.0086

[18] Brevik, E. C., \& Sauer, T. J. (2015). The past, present, and future of soils and human health studies. Soil, 1, 35-46. http://doi.org/10. 5194/soil-1-35-2015

[19] Daigh, A. L., Dick, W. A., Helmers, M. J., Lal, R., Lauer, J. G., Nafziger, E., ... Mukherjee, A. (2018). Yields and yield stability of no-till and chisel-plow fields in the midwestern US Corn Belt. Field Crops Research, 218, 243-253. http://doi.org/10.1016/j.fcr.2017.04.002 
Journal of Electronics and Informatics (2021)

Vol.03/ No.01

Pages: 23-35

https://www.irojournals.com/iroei/

DOI: https://doi.org/10.36548/jei.2021.1.003

[20] Delgado, J., Barrera Mosquera, V., Escudero López, L., Cartagena Ayala, Y., Alwang, J., Stehouwer, R., ... Valverde, F. (2019). Conservation agriculture increases profits in an Andean region of South America. Agrosystems, Geosciences \& Environment 2, 180050.

[21] Abdelfattah, A., Malacrinò, A., Wisniewski, M., Cacciola, S.O., Schena, L., 2017. Metabarcoding: a powerful tool to investigate microbial communities and shape future plant protection strategies. Biological Control. http://dx.doi.org/10.1016/j. biocontrol.2017.07.009.

[22] Akhtar-Schuster, M., Stringer, L.C., Erlewein, A., Metternicht, G., Minelli, S., Safriel, U., Sommer, S., 2017. Unpacking the concept of land degradation neutrality and addressing its operation through the Rio Conventions. Journal of Environmental Management 195, 4-15.

[23] Allan, E., Manning, P., Alt, F., Binkenstein, J., Blaser, S., Bluethgen, N., Boehm, S., Grassein, F., Hoelzel, N., Klaus, V.H., Kleinebecker, T., Morris, E.K., Oelmann, Y., Prati, D., Renner, S.C., Rillig, M.C., Schaefer, M., Schloter, M., Schmitt, B., Schoening, I., Schrumpf, M., Solly, E., Sorkau, E., Steckel, J., Steffen-Dewenter, I., Stempfhuber, B., Tschapka, M., Weiner, C.N., Weisser, W.W., Werner, M., Westphal, C., Wilcke, W., Fischer, M., 2015. Land use intensification alters ecosystem multifunctionality via loss of biodiversity and changes to functional composition. Ecology Letters 18, 834-843.

[24] Ball, B.C., Guimarães, R.M.L., Cloy, J.M., Hargreaves, P.R., Shepherd, T.G., McKenzie, B.M., 2017. Visual soil evaluation: a summary of some applications and potential developments for agriculture. Soil and Tillage Research 173, 114-124.

ISSN: 2582-3825 (online) 